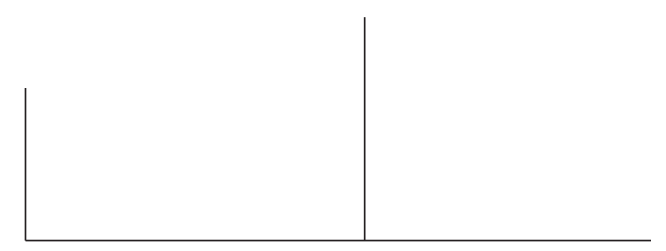

Rev. Latinoam. Psicopat. Fund., V, 1, 128-151

\title{
Feminilidade e castração seus impasses no discurso freudiano sobre a sexualidade feminina*
}

\author{
Zeferino Rocha
}

No presente trabalho desejo submeter à discussão dos leitores o modo como Freud se confronta com o problema da castração em três momentos decisivos da trajetória de sua teoria sobre a sexualidade feminina. As três partes do trabalho procuram cobrir esta trajetória. A primeira discute o problema da castração biológica da mulher e de sua conseqüente sexualidade que Freud considera inferior, quando comparada à sexualidade masculina. A segunda mostra a importância e o destino da castração simbólica na estruturação do psiquismo e na tarefa do tornar-se mulher, embora isto não apareça no texto manifesto do discurso freudiano. E, finalmente, a terceira parte relaciona feminilidade e desamparo em um registro que se poderia dizer ontológico, tendo como referência o artigo de 1937 sobre a análise terminável e interminável, no qual Freud coloca em destaque o "rochedo de base" da castração sem, no entanto, dar-lhe a interpretação que nos parece mais adequada.

Palavras-chave: Sexualidade feminina, castração, feminilidade, desamparo

* Este trabalho foi apresentado no VII Encontro comemorativo dos 20 anos do Centro de Pesquisas em Psicanálise e Linguagem (CPPL), realizado na cidade do Recife, nos dias 3, 4 e 5 de maio de 2001, cuja temática central foi "Imagens e figurações do feminino na psicanálise e na cultura". 


\section{Objetivo do trabalho}

É meu propósito, no presente trabalho, descrever de que modo Freud se confronta com a problemática da castração em três momentos decisivos da sua teoria sobre a sexualidade feminina. Como veremos, esta confrontação acontece em três registros de reflexão diferentes. O primeiro, que se poderia dizer biológico e anatômico, é trabalhado no livro Três ensaios sobre a teoria sexual (1905) e, nele, a mulher, comparada ao homem, aparece como um ser "a-menos", ${ }^{1}$ estigmatizada pela ausência do pênis, como se fosse portadora de uma sexualidade inferior. Por vezes, esta inferioridade assume, no texto freudiano, a dimensão e a radicalidade de uma Minderwertigkeit verdadeiramente ontológica.

O segundo registro, que poderíamos chamar de simbólico, aparece quando Freud, depois de um longo percurso, introduz, em 1923, a fase fálica e o primado do phallus ${ }^{2}$ na organização pré-genital da libido, descobrindo, assim, o valor fundamental do complexo de castração, bem como sua união estruturante com o complexo de Édipo.

Embora não dispusesse, no seu campo de pesquisa, dos elementos que definiram, depois, a especificidade da abordagem estruturalista, Freud, no entanto, deixa implícito nos seus textos que a castração, mediante a qual se faz a passagem do imaginário da relação dual com a mãe para o simbólico da relação ternária edipiana, adquire uma importância decisiva

1. A expressão é de Carlos Augusto Nicéas no seu artigo "Primado do falo e castração feminina". In: BIRMAn, Joel e NicÉAs, Carlos Augusto (orgs.). O feminino: aproximações, p. 55-84.

2. Embora o termo phallus seja correta e habitualmente traduzido, na língua portuguesa, pela palavra falo, eu vou conservar a grafia latina, phallus, como fazem as línguas alemã, inglesa e francesa, porque ela me parece mais expressiva para traduzir a dimensão mítica e simbólica que tem o phallus não só na literatura dos povos primitivos, mas também na teoria psicanalítica. 
nos destinos da constituição do psiquismo e da identidade sexual tanto do homem quanto da mulher, revestindo, dessa forma, a importância e o significado (os alemães diriam a Bedeutung) de um conceito estruturante (Grundbegriff) para a constituição da subjetividade.

Nesse contexto, era de esperar que a mulher deixasse de ser estigmatizada como um "a-menos" e passasse a ser vista como um ser de valor e dignidade "iguais" ao do homem, pois quando o phallus é olhado na sua dimensão imaginária e simbólica, não é privilégio exclusivo nem da masculinidade nem da feminilidade. Todavia, não é isto que dizem os textos de Freud, ao menos em seu conteúdo manifesto.

Finalmente, em um dos últimos escritos e num registro que se poderia dizer ontológico e existencial, Freud, mais uma vez, relaciona feminilidade e castração, apresentando-as como reveladoras do enigma da finitude do ser humano. Aqui também esta nova dimensão, que se descortinava promissora para o estudo da castração em uma estreita relação com o desamparo, parece ter sido abortada por causa do "biologismo" de Freud, para quem, mesmo neste novo contexto, a "anatomia" continuava sendo o "destino". ${ }^{3}$

Trabalhar essas três dimensões - biológica, simbólica e ontológica - da castração na trajetória do estudo freudiano da sexualidade feminina é o que me proponho como objetivo no presente trabalho.

\section{Percurso metodológico}

Para tanto dividirei o trabalho em três partes e percorrerei a trilha do seguinte roteiro metodológico:

a) na primeira parte, tentarei resumir o essencial do que Freud escreve sobre a sexualidade feminina nos "Três ensaios..." (1905) e no artigo "As teorias sexuais infantis" (1908);

b) na segunda, situarei feminilidade e castração no contexto da fase fálica, de sua lógica específica e daquilo que o próprio Freud designou como sendo o primado do phallus;

c) na terceira, partindo do que Freud escreve no capítulo oitavo do artigo "Análise terminável e interminável" (1937), abordarei a articulação da castração com o desamparo e questionarei se o termo "feminilidade", empregado por Freud, é

3. Parafraseando Napoleão, Freud costumava dizer: "Die Anatomie ist das Schicksal". Cf. Sigmund Freud. "Uber die allgemeinste Erniedrigung des Liebeslebens" (1912). In: "Beiträge zur Psychologie des Liebeslebens-II" (1912), p. 209. Ver também "Der Untergang des Ödipuskomplexes" (1924), p. 249. 


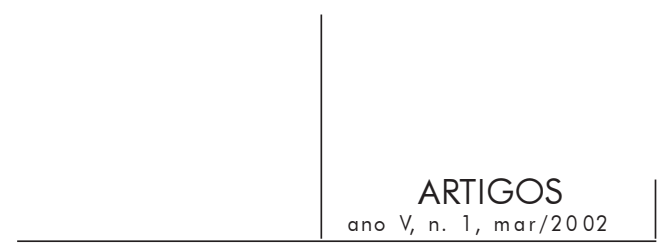

adequado para designar o que ele quis significar com a metáfora do "rochedo de base" da castração e da angústia do Real (Realangst) que lhe é associada.

Tendo em vista a insatisfação que Freud (1933, p. 565) não dissimulou em relação à sua teoria sexual feminina e seguindo o conselho que ele próprio deu, quando mandou que interrogássemos os poetas, ${ }^{4}$ se quiséssemos conhecer melhor o enigmático mundo da mulher, farei, no término da conferência, uma breve alusão ao que ele escreveu sobre o enigma feminino no artigo "O motivo da escolha dos cofrezinhos", no qual comenta duas conhecidas passagens das peças $O$ mercador de Veneza e Rei Lear, de W. Shakespeare (Freud, 1913, p. 181-94).

$\mathrm{Na}$ linguagem simbólica do mito e das lendas, este artigo, pouco citado na literatura psicanalítica, coloca em destaque o enigma da feminilidade, lembrando as figuras femininas que nos acompanham, no desenrolar da vida, do berço ao túmulo, vale dizer, a mulher-mãe que nos concebeu e nos deu a vida; a mulher-amada com quem partilhamos o amor durante a vida, e, finalmente, a Mãe-Terra que no término da vida novamente nos acolhe em seu seio (Ibid., p. 193).

Aqui, como em muitos lugares da Obra de Freud, o seu pensamento psicanalítico - particularmente quando se trata do que há de mais profundo no acontecer do psiquismo e da sexualidade humana - articula, de modo muito interessante, dois registros de reflexão diferentes que, antes de se excluírem, complementam-se e estão muito mais próximos um do outro do que geralmente se pensa. São eles: o registro e a linguagem lógica do pensamento científico e o registro e a linguagem simbólica do mito e das lendas.

Há certas realidades humanas - e a feminilidade certamente é uma delas - que não podem ser totalmente desveladas, porque o seu sentido é inesgotável e o seu segredo é da ordem do indizível. Denis de Rougemont (s/d., p. 18), no clássico e belo livro $O$ amor no ocidente, refere-se a essas realidades e diz que elas precisam ser resgatadas e postas ao abrigo das investidas indiscretas da razão ilustrada.

Pois bem, o mito revela e oculta o segredo dessas verdades, quando queremos conhecer algo sobre seu segredo. Dir-se-ia que ele vela por elas, quando o reducionismo desmistificador da razão crítica iluminista ameaça destruir o seu enigma e o seu mistério.

4. "Querem os senhores saber mais sobre a feminilidade (Wollen Sie mehr über die Weiblichkeit wissen), então indaguem suas próprias experiências de vida (so befragen Sie Ihre eigenen Lebenserfahrungen), ou dirijam-se aos poetas (oder Sie wenden sich an die Dichter), ou aguardem até que a ciência possa lhes dar informações mais profundas e melhor correlacionadas (oder Sie warten, bis die Wissenschaft Ihnen tiefere und besser zusammenhängenden Auskünfte geben kann)". 


\section{Primeira Parte}

\section{A castração biológica: a mulher, um ser marcado por um "a-menos"}

Não me demorarei nesta primeira parte, pois as idéias que Freud nela desenvolve sobre a sexualidade feminina não convencem e melhor teria sido que ele jamais as tivesse escrito. Freud, inegavelmente, era um homem de seu tempo. Mas custa acreditar que um inovador que, em tantos pontos, esteve muito além de seu tempo, tenha defendido a tese da inferioridade da sexualidade feminina, quando comparada com a masculina. De fato, nos textos desta primeira parte, a sexualidade da mulher tem a sexualidade masculina como paradigma e termo de comparação. O próprio Freud (1925, p. 258) o diz:

Quando estudamos as primeiras configurações psíquicas da vida sexual infantil, tomamos sempre como objeto [de estudo] a criança do sexo masculino, o pequeno menino. Pensávamos que o mesmo deveria acontecer com as meninas, embora numa modalidade de alguma forma diferente. Não se podia mostrar claramente em que, no decurso do desenvolvimento, esta diferença devia encontrar-se.

Freud (1925a, p. 36), portanto, esperava encontrar um paralelo completo entre os dois sexos, mas isto, como ele próprio reconheceu, não aconteceu. E o que resultou dessa comparação? Resultou, simplesmente, que a mulher foi estigmatizada, na sua realidade e atividade sexuais, com um "a-menos", causa de sua inferioridade. E este estigma marcou a visão freudiana da mulher, a qual se conservou ligada a uma tradição que, desde os gregos, transmitia, para a cultura ocidental, a imagem da mulher como a de um "homem mutilado". 5

Segundo os padrões ideológicos desta tradição, que hoje vem sendo insistentemente questionada, valorizava-se o ser que possuía o pênis e desvalorizavase aquele que não o possuía. Freud, na medida em que, numa perspectiva biológica, correlacionava o fálico à posse do pênis e o castrado à sua ausência, foi levado a descrever a sexualidade feminina como inferior, quando comparada à sexualidade masculina.

Mesmo após a introdução da fase fálica, seus textos, que abordam a questão sexual feminina, continuam ressaltando a Minderwertigkeit, vale dizer, a inferioridade da sexualidade feminina. Esta inferioridade justifica, aos seus olhos, inúmeras diferenças do perfil psicológico da mulher. Para dar um só exemplo, lembro que, para

5. No VII Encontro do CPPL, Eliane Robert Moraes, em uma belíssima conferência sobre "Os monstros e o feminino", recordou que no De Generatione et Corruptione, de Aristóteles, a mulher já aparece como um "homem mutilado" e sua anatomia é vista como uma "forma inacabada", conseqüentemente "monstruosa". 


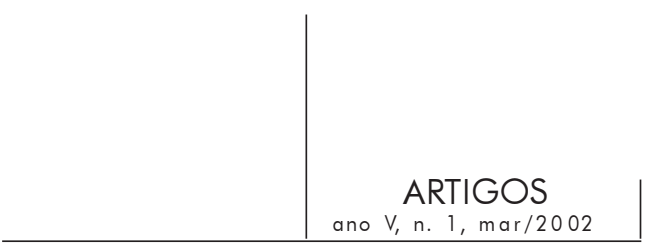

ele, a "vaidade" (Etelkeit) e o "pudor" (Scham) têm a finalidade de compensar e de ocultar "a inferioridade sexual originária da mulher" (die ursprüngliche sexuelle Minderwertigkeit des Weibes) (FREUD, 1933, p. 562). A esta inferioridade estariam relacionados marcantes traços da feminilidade, tais como: o ciúme, a inveja, um superego frágil, poucas contribuições para a História da Civilização, pouco senso de justiça, bem como uma capacidade sublimatória bastante limitada.

O período inicial do estudo freudiano da sexualidade feminina foi inteiramente dominado pela crença infantil na universalidade do pênis. De fato, na fase genital infantil, o menino investe e supervaloriza narcisicamente o próprio pênis e, movido por uma intensa curiosidade, levanta inúmeras questões ligadas ao enigma da sexualidade. Não recebendo dos adultos respostas adequadas, nem esclarecedoras, ele começa a fabular, no jogo de suas fantasias, algumas "teorias" sexuais que adquirem, para ele, a força persuasiva de uma verdadeira crença. Entre essas crenças, sobressai a de que todos os seres humanos têm um pênis. Freud (1905, p. 100) escreve: "Para o menino, é evidente que um órgão genital como o seu deve ser atribuído a todas as pessoas que ele conhece". Quem não o tem, ou ainda vai tê-lo, ou, então, tinha e foi castrado.

Sabe-se que, mesmo quando desmentida pela experiência perceptiva, esta crença não se desfaz e um substituto tenta suprir a ausência do pênis na mulher. Na fase fálica, este substituto é o clitóris, que a ciência biológica, destaca Freud (Ibid., p. 101), "não pode deixar de reconhecer como um verdadeiro substituto do pênis", e, desse modo, confirma a crença infantil na sua universalidade. Se o clitóris é homônimo do pênis, a sexualidade clitoriana é de natureza masculina, ou, para dizêlo com as palavras do próprio Freud, "tem um caráter inteiramente masculino (durchaus männlichen Charakter)” (Ibid., p. 123).

Assim sendo, não é de admirar que as meninas sejam dominadas pela inveja do pênis (Penisneid), uma inveja que "culmina no desejo, rico em conseqüências de ser também um menino (auch ein Bub zu sein)", e que os homens passem freqüentemente a nutrir "uma duradoura depreciação pelo outro sexo (eine dauernde Geringschätzung des anderen Geschlechts)", vale dizer, pela mulher desprovida do pênis (Ibid., p. 101n) ${ }^{6}$.

E, com palavras ainda mais enfáticas, escreve ele no texto de 1931 sobre a sexualidade feminina: "A mulher reconhece o fato de sua castração e, com isso também, a superioridade do homem e sua própria inferioridade, e se revolta contra essa situação desagradável" (FREUD, 1931, p. 279)7.

6. Nota acrescentada em 1920.

7. Das Weib anerkennt die Tatsache seiner Kastration und damit auch die Überlegenheit des Mannes und seine eigene Minderwertigkeit, aber es sträubt sich auch gegen diesen unliebsamen Sachverhalt. 
Resumindo, pode-se dizer que nessa primeira fase, a vida sexual da mulher reveste "um caráter inteiramente masculino". Somente quando a menina recalca a sexualidade clitoriana masculina é que existe, para ela, a possibilidade de se tornar uma mulher. Para tanto, faz-se necessário uma Geschlechtswechsel des Weibes, isto é, uma "mudança de sexo da mulher" - as palavras não são minhas, mas do próprio Freud (1905, p. 125; 1931, p. 278) -, e, nessa mudança, ele vê a essência da feminilidade (das Wesen der Weiblichkeit).

Notemos também que, nesta altura da evolução de seu pensamento, Freud $(1905 \text {, p. } 123 \text {, n. } 1)^{8}$ ainda valoriza bastante a relação, freqüentemente estabelecida, do ponto de vista psicológico, entre os pares "masculino"-"atividade" e "feminino""passividade". Para ele, esta relação é "essencial e muito utilizada na psicanálise". Neste contexto, afirma - mirabile dictu! - que a própria libido, por causa de sua atividade, é de natureza masculina.

Não acho necessário deter-me por mais tempo na crítica ao modo como Freud coloca o problema da sexualidade feminina nesse registro da castração biológica. Sua preocupação biologizante, de um lado, e o fato de não ter levado em consideração os "fatores culturais" responsáveis pela imagem "inferiorizada" da mulher em uma civilização patriarcal dominada pelo discurso masculino, de outro, resultaram na maneira infeliz como foi elaborada a tese da inferioridade da sexualidade feminina, inteiramente dissociada do pensamento inovador de Freud, que, sob tantos outros aspectos, foi um homem de vanguarda, muito além de seu tempo.

Freud, nesta altura de sua obra, ainda não tinha descoberto a universalidade do complexo de castração. Esta só se torna clara aos seus olhos, quando é introduzido o primado do phallus. De fato, esse primado é a condição indispensável para que se possa apreciar, no seu justo valor, o significado da Castração e seu papel decisivo na estruturação da subjetividade. "Parece-me" - escreve Freud (1923, p. 239) - "que só se pode verdadeiramente avaliar o significado do complexo de castração, quando se leva em consideração sua origem na fase do primado do phallus". ${ }^{9}$ É o que passaremos a ver em seguida.

8. "Man gebraucht männlich und weiblich bald im Sinne von Aktivität und Passivität, bald im biologischen und dann auch im soziologischen Sinne (Emprega-se masculino e feminino seja no sentido de atividade e passividade, seja num sentido biológico seja ainda num sentido sociológico). Die erste dieser drei Bedeutungen ist die wesentliche (o primeiro desses três sentidos é o essencial) und die in der Psychoanalyse zumeist verwertbare (e o mais empregado em psicanálise)".

9. "Es scheint mir nur, dass man die Bedeutung des Kastrationskomplexes erst richtig würdigen kann, wenn man seine Entstehung in der Phase des Phallusprimats mitberücksichtigt". 


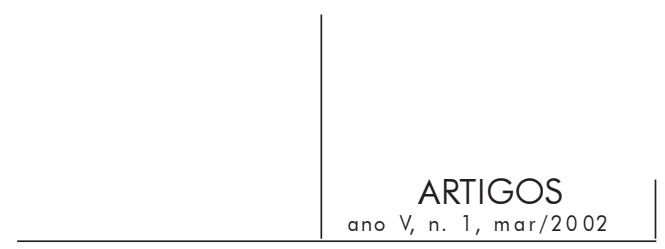

Segunda Parte

\section{A castração simbólica e seu destino decisivo na estruturação do psiquismo e da identidade sexual do homem e da mulher}

O artigo de 1923 - "A organização genital infantil" - introduz a fase fálica na organização pré-genital da libido. Trata-se de uma fase genital pré-genital, ou, como Freud prefere dizer, genital infantil. É genital porque seu objeto de investimento libidinal é o órgão genital masculino, o pênis. Mas genital pré-genital, porque o pênis, em questão, não é o pênis em si, órgão anatômico característico da sexualidade masculina, mas o pênis enquanto símbolo, atributo ou insígnia do phallus. Por esta razão, Freud não deu o nome de peniana a esta nova fase do desenvolvimento da libido. Ele a designou com o nome de fase fálica.

Apesar disso, e sem camuflar uma grande ambigüidade por falta de uma distinção precisa entre pênis e phallus, Freud afirma que, na organização genital infantil, "só um órgão genital, o masculino, é importante para os dois sexos" (für beide Geschlechter nur ein Genital, das männliche, eine Rolle spielt). O que deixa entender que, para ele, é o pênis, na sua realidade anatômica, que está em jogo na fase fálica do desenvolvimento libidinal. E, quase simultaneamente a esta afirmação, acrescenta: "Assim, não existe um primado genital, mas um primado do phallus (ein Primat des Phallus) (Ibid., p. 238).

Não se pode deixar de notar a grande ambigüidade destas afirmações: na fase genital infantil, só existe o órgão sexual masculino - o pênis - e só ele conta para os dois sexos, mas isto não lhe confere nenhum primado, porque o primado é do phallus. A ambigüidade se explica porque Freud não diz o que entende por phallus nem se empenha em fazer uma distinção rigorosa entre phallus e pênis.

Por não ter feito isso, ele continua, durante todo o percurso de seu trabalho de teorização sobre a sexualidade feminina, prisioneiro de uma perspectiva biológica, dando um lugar de realce, nas atividades fálicas, ao pênis do menino e ao clitóris da menina, correndo, assim, o risco de não ser compreendido mesmo por discípulos que lhe eram muito próximos.

Foi o que aconteceu ao seu biógrafo Ernest Jones (1969), o qual, em um controvertido artigo sobre a fase fálica, não tendo visto, no conteúdo manifesto do texto freudiano, uma distinção mais clara entre pênis e phallus, terminou criticando vigorosamente o que chamou de "falocentrismo" freudiano.

Pênis e Phallus

E, no entanto, pênis e phallus pertencem a dois registros totalmente diferentes. O pênis é, sem dúvida, um órgão narcisicamente muito investido e, enquanto órgão 


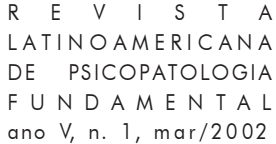

sexual, tem um papel decisivo na diferenciação entre o sexo masculino e o sexo feminino por ocasião da fase genital adulta (embora - como é sabido - masculinidade e feminilidade não se esgotem, de maneira alguma, nesta diferença de sexos). A identidade sexual do homem e da mulher, além da diferença orgânica dos sexos, supõe um complexo processo de identificações no qual estão em jogo as instâncias ideais do ego, ego-ideal, ideal do ego e superego. É na encruzilhada dessas identificações, e no trabalho estruturante da Lei do Pai, que se constituem a subjetividade humana e a identidade sexual dos seres humanos.

O Phallus é da ordem dos símbolos. Infelizmente, em virtude de uma exagerada preocupação "biologizante" que está sempre presente no seu estudo da sexualidade, Freud não explorou, como se esperava, as dimensões imaginária e simbólica da fase e das atividades fálicas. Inegavelmente coube a Lacan o merecimento de ter colocado, em primeiro plano, tanto a dimensão imaginária e simbólica do phallus, quanto seu lugar de realce na reflexão psicanalítica em geral, e na teoria sexual freudiana, em particular. ${ }^{10}$

$\mathrm{Na}$ fase fálica, a diferença anatômica dos sexos ainda não é valorizada pela criança e, embora ela já saiba diferenciar a mulher do homem e o homem da mulher, esta diferença ainda não é correlacionada com a diversidade de seus órgãos genitais. Ou, dito de outro modo, na fase fálica não existe ainda uma representação psíquica do sexo feminino e a oposição que a caracteriza não é a distinção entre masculino e feminino, mas a oposição fálico-castrado. O fálico, porém, não é privilégio do masculino, nem o castrado do feminino.

\section{A lógica fálica}

Para melhor esclarecer o significado da oposição fálico-castrado, que é essencial na fase fálica, talvez seja oportuno lembrar aquilo que Jean Laplanche chamou de lógica fálica e sua aplicação à sexualidade humana. ${ }^{11}$ Ela pode ser pensada, tendo como referência analógica a lógica do conceito. Esta conhece e define dois tipos de oposição: a oposição dos contrários e a dos contraditórios.

Num sistema de várias cores contrárias, elas não podem ser afirmadas simultaneamente de um mesmo sujeito. Uma coisa não pode ser verde e azul ao mesmo tempo. Mas a negação do azul não remete necessariamente ao verde, ela pode

10. Como desejo restringir meu trabalho ao texto freudiano, vou apenas remeter o leitor ao artigo de Jacques Lacan "A significação do falo" (Die Bedeutung des Phallus). In: Escritos, p. 692-703.

11. Veja-se a este respeito as magistrais reflexões de Jean Laplanche no seu livro Problemáticas II. Castração. Simbolizações, p. 51-73. O que apresento, aqui, sobre a lógica fálica e a dialética dos conceitos contraditórios e contrários, é apenas um resumo do que é exposto nesse seu livro. 


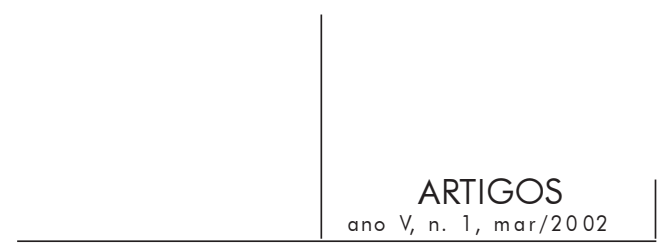

remeter ao vermelho, ao amarelo ou, ainda, a outras cores. ${ }^{12}$ Todavia, em um sistema fechado de dois valores apenas (pensemos em um sistema bicolor preto e branco), a oposição se faz entre os dois termos contraditórios. Então, o branco pode definirse pelo não-preto e o preto pelo não-branco.

Os conceitos, porém, não existem hipostasiados em si mesmos. A lógica do conceito deve ser inserida numa lógica do juízo e da atribuição. Os conceitos são atribuídos a um sujeito. E o atributo tanto pode ser uma qualidade, quanto uma insígnia. Posso atribuir, por exemplo, o azul à imensidade infinita do céu e formar a proposição: o céu é azul, e posso também atribuir o vermelho à cor do sangue e dizer: o sangue é vermelho.

Mas essas duas cores (azul e vermelho) podem também ser concebidas como "insígnias" de dois partidos não só contrários, mas contraditórios. Então, a lógica opera em um sistema de dois termos, e quem for do partido azul não será do vermelho e vice-versa. É o que acontece com os partidos e os cordões de nossos pastoris nordestinos. Uma ressalva, porém, deve ser feita, pois para o nordestino que, como diria Bandeira, "fala gostoso o português do Brasil", o vermelho se diz "encarnado". No pastoril, os cordões que se opõem são o azul e o encarnado. E se vocês me lembrarem a figura da "diana", querendo, assim, comprometer a bipolaridade do sistema pastoril, eu, de minha parte, lembraria que a diana não tem partido, "o seu partido são os dois cordões". A diana, portanto, está fora e acima do sistema. Por isso, o seu papel é tão cobiçado. Como quer que seja, as cores azul e vermelho, como qualidades, são cores contrárias e, como insígnias, são contraditórias.

Dentro desta lógica do conceito, Laplanche nota ainda que a qualidade nãoverde, por exemplo, é uma abstração. Para ser considerada como uma verdadeira qualidade, é preciso que o não-verde se oponha a um objeto qualquer, que tenha uma determinada cor (azul, por exemplo). Quando consideramos o azul e o encarnado como insígnias dos partidos, ou cordões do pastoril, o não-azul não é mais uma abstração, ele tem uma dimensão real, pois designa concretamente a pessoa do cordão encarnado, o partido que a ele se opõe contraditoriamente. Neste caso, poder-se-ia dizer que o não-azul pode ser percebido porque ele se concretiza na realidade do encarnado, um dos termos da contradição. Se é não-azul, é encarnado. Se é nãoencarnado, é azul. ${ }^{13}$

12. Laplanche acrescenta que a oposição de contrários transformar-se-ia numa oposição de contraditórios se reuníssemos, num só conceito (por exemplo no conceito de não-branco), o conjunto das demais cores e opuséssemos esse conjunto ao branco. Nesse caso, a negação do branco remeteria ao não-branco e a do não-branco ao branco.

13. Depois da apresentação deste meu trabalho no VII Encontro do CPPL, uma ouvinte me procurou para dizer que o exemplo das cores não era bom para caracterizar a dialética dos contrários e contraditórios, porquanto as cores são complementares. Eu the respondi que, levando isso em 


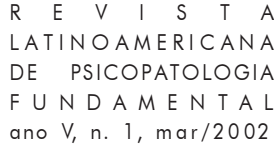

Pois bem, aplicando essa lógica dos conceitos contraditórios à fase fálica, podemos dizer que a percepção da ausência do pênis na mulher não é um absurdo. Esta não-presença, esta percepção da ausência do pênis, concretiza-se na realidade psíquica imaginária do objeto fálico. Sendo assim, fica mais fácil compreender porque Freud diz que, na fase fálica, não temos dois sexos opostos por insígnias diferentes, mas apenas um sexo que é marcado, ou não, pela insígnia fálica.

Desse modo, é totalmente improcedente, na perspectiva da lógica fálica, a identificação da insígnia fálica com o masculino e a sua ausência com o feminino. O phallus é único e se opõe contraditoriamente ao não-fálico, ou seja, ao castrado. O phallus não se opõe a um outro órgão, que seria o órgão-insígnia da feminilidade.

Se é no órgão sexual masculino que o phallus encontra uma representação imaginária e simbólica e, como tal, foi objeto de veneração em cultos primitivos e nos rituais de iniciação, é preciso não esquecer que, nesses rituais e cultos, o que estava em jogo era, sem dúvida, o órgão viril, mas um órgão viril separado do resto do corpo e em estado contínuo de ereção. Ora, só isto seria suficiente para invalidar sua identificação com o pênis, enquanto órgão anatômico masculino, pois este nem é separável do resto do corpo, nem está sempre em estado de ereção.

\section{As deusas fálicas}

A este propósito seria interessante lembrar uma passagem de "Uma lembrança de infância de Leonardo da Vinci" (1910, p. 87-159) em que Freud interpreta o sentido daquele pássaro - provavelmente um falcão (Geier) - o qual, de conformidade com a fantasia de Leonardo, pousou no seu berço e lhe bateu várias vezes com a cauda nos lábios. Para Freud, não há dúvida de que o pássaro, em questão, era uma representação fantasmática da mãe de Leonardo que, certamente, o cobria de beijos para compensar suas frustrações afetivas e sexuais de jovem mãe abandonada pelo esposo.

E para mostrar de que modo o imaginário do artista renascentista pôde ter sido influenciado para construir semelhante fantasia, Freud lembra uma lenda egípcia, conhecida também na cultura latina e não fora do alcance das leituras de Leonardo. Segundo a lenda, numa determinada espécie de pássaros só existiam fêmeas e nenhum macho. As fêmeas reproduziam-se sem a participação do macho, pois eram fecundadas pelo vento, quando se encontravam em pleno vôo. Daí, comenta Freud, o interesse dos padres da Igreja (Kirchenväter) pela lenda, pois, nela, encontravam um sugestivo exemplo da História Natural para comprovar a doutrina da Imaculada Conceição da Virgem Maria.

consideração, seria preferível procurar um outro exemplo, mas, de qualquer modo, no plano formal da lógica dos conceitos, o que importa levar em consideração não é tanto as propriedades reais das cores, mas sua significação simbólica, sua dimensão de atributo ou insígnia. 


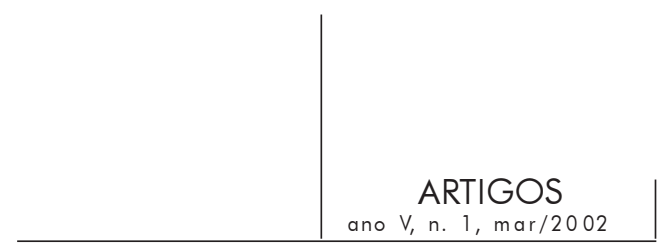

Na mitologia egípcia, temos ainda a figura da deusa-mãe com cabeça de falcão (geierköpfige mütterliche Gottheit). Os egípcios figuravam essas deusas com representações fálicas. Em seus corpos femininos, os seios tinham uma forma fálica, ou seja, tinham a forma de um pênis separado e em estado de ereção. Essas deusas fálicas simbolizavam a força criadora e primitiva da Natureza. Freud ainda observa que em nenhuma dessas figuras de deusas fálicas existia, realmente, a combinação dos genitais dos dois sexos (keine von ihnen vereinigt die wiklichen Genitalien beider Geschlechter) como às vezes acontece nas más-formações anatômicas. Eram os seios, característicos da maternidade, que adquiriam a forma fálica, exatamente como acontece nas representações infantis do corpo materno. (Ibid., p. 123)

Na mitologia, portanto, as insígnias fálicas, simbolizadas sob a forma do pênis, eram também atribuídas às deusas, por conseguinte às mulheres. Elas não são, pois, privilégio dos homens. Mas voltemos à fase fálica e vejamos de que modo a castração, nela, adquire um valor estruturante e decisivo para a tarefa do tornar-se mulher.

\section{Castração e Édipo}

Embora as dimensões imaginária e simbólica do phallus não apareçam no conteúdo manifesto dos textos freudianos, elas, todavia, estão implícitas naquilo que ele diz sobre as fases pré-edipianas do desenvolvimento libidinal, particularmente quando analisa a "ursprüngliche Mutterbindung", vale dizer, a ligação originária da criança com a mãe.

Freud (1931, p. 281) chama a atenção para a imensa ambivalência desta união. É uma união dual inteiramente imaginária, na qual mãe e filho fusionam-se numa mônada sem abertura para a alteridade. Além do mais, nela, o amor infantil é um amor sem medida (masslos), exige exclusividade (Auschliesslichkeit), não se satisfaz com fragmentos (gibt sich nicht mit Anteilen zufrieden). É, portanto, grande demais a avidez da libido infantil (So gross ist die Gier der kindlichen Libido!) (Ibid., p. 283) ${ }^{14}$. Porque incapaz de satisfação, esta kindlichen Libido é também sem objetivo (ziellos), ou, dito de outro modo, é ilusória, uma vez que necessariamente fadada à decepção, que funciona qual nova fonte de hostilidade, reforçando e acentuando a ambivalência do desejo infantil em relação à figura materna.

Lacan deu o devido destaque a esta união originária com a mãe (ursprüngliche Mutterbindung) quando, no primeiro tempo da sua leitura do Édipo, fez da figura da mãe o personagem central da experiência edípica. A criança, nas coordenadas imaginárias da relação dual, identifica-se com o objeto fálico e deseja completar a

14. O fato de Freud ter utilizado, aqui, o adjetivo "kindliche" deixa entender que ele está se referindo tanto ao menino quanto à menina. 
incompletude da mãe. Identificada com o objeto fálico do desejo materno, a criança, menino ou menina, torna-se apenas desejo de seu desejo. Nesse contexto, a lógica fálica opõe, contraditoriamente, ser ou não-ser o phallus. Aprisionada pelas ambições narcísicas da mãe fálica, a criança torna-se o phallus imaginário da mãe e condenase a jamais poder tornar-se um ser desejante, porque incapaz de reconhecer e de assumir a falta, negada pela ilusória plenitude da união fálica.

Na encruzilhada dessa onipotência fálica ilusória e da decepção ou desilusão a que está condenada, Freud coloca a Lei do Pai e a Castração na sua dupla função de Lei e de sanção da Lei. Aliás, é próprio da Lei ter uma dupla face: a face de interdição e a outra de estruturação e de ordenação. Se não há lei sem desejo, pois a lei vem precisamente pôr limites à desmedida do desejo, é também certo que não pode haver desejo sem lei, pois a lei tem um papel estruturante na ordem do desejo. Um desejo sem lei é uma contradição, pois significa um desejo ilimitado e o limite e a falta estão na essência mesma do desejo.

A castração, portanto, para dizê-lo com Laplanche, é, ao mesmo tempo, castigo e promessa. Castigo para punir a transgressão da Lei, e promessa de realização humana porque só ela possibilita a passagem da ordem imaginária para a ordem simbólica.

\section{Penisangst e Penisneid}

É por causa desta dupla face da castração que Freud (1914, p. 59) lhe atribui dois destinos diferentes, no Édipo masculino e no Édipo feminino. No primeiro, enquanto Penisangst, a castração, como castigo, é a saída do Édipo masculino. No segundo, enquanto Penisneid, a castração, como promessa, é a porta de entrada para o Édipo da menina.

A Penisangst leva o menino a renunciar aos desejos fálicos de onipotência narcísica, segundo os quais ele se identifica com o phallus imaginário, objeto do desejo materno. Enquanto rivaliza com o pai imaginário, suposto dono do desejo da mãe, o menino ainda continua prisioneiro de suas ambições fálicas. Estas só são abandonadas quando ele, pela mediação da mãe, aceita a Lei do Pai, vale dizer, assume a castração numa elaboração simbólica, o que lhe abre a porta de saída do Édipo e lhe mostra o caminho da identificação com a figura paterna, ou com alguém que a represente, figura que funciona como modelo ideal para o seu ego, o que the assegura os fundamentos da sua identidade masculina e a construção de seu futuro de homem.

O Penisneid tem um destino diferente. Quando descobre que a "mãe fálica" é, na verdade, como toda e qualquer mulher, um ser biologicamente castrado, a menina assume uma atitude ambivalente em relação à castração, porquanto, de um lado, não pode deixar de reconhecê-la e, de outro, revolta-se contra ela. Segundo Freud (1931, p. 279), desta atitude de revolta partem três possíveis direções que podem selar o desenvolvimento da sexualidade feminina: 


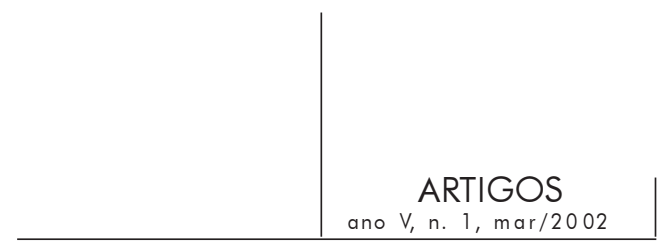

a) "o afastamento geral da sexualidade";

b) "o complexo de masculinidade";

c) "a configuração final normal da mulher." 15

Dir-se-ia que a mulher, mesmo quando consegue a "configuração final normal" de sua sexualidade, ainda tem que se debater com o complexo de Édipo, pois o Édipo feminino não conhece uma saída, nem uma resolução, como o masculino. Ele é "o resultado final (Endergebnis) de um desenvolvimento bastante demorado (einer längeren Entwicklung); ele não é destruído pela influência da castração (er wird durch den Einfluss der Kastration nicht zerstört), mas é, por ela, criado (sondern durch ihn geschaffen), e escapa das fortes e hostis influências (er entgeht den starken feindlichen Einflüssen) que, no homem, agem sobre ele de modo destruidor (die beim Mann zerstörend auf ihn einwirken) e, freqüentemente, não é, de modo algum, superado pela mulher (ja er wird allzuhäufig vom Weib überhaupt nicht überwunden). (Ibid., p. 279)

Mais uma vez o discurso freudiano sobre o destino do tornar-se mulher é ambíguo, e a causa da ambigüidade é, novamente, o fato de Freud não ter dado à castração simbólica um lugar de destaque na sua abordagem psicanalítica do Édipo. Quando, pela segunda vez, a menina se desilude de suas ambições fálicas, vale dizer, quando desiste de querer receber do pai o pênis, ou um filho, como equivalente simbólico do pênis - ela, de modo semelhante ao menino na saída do Édipo - está em condições de poder elaborar simbolicamente o verdadeiro sentido de sua castração, de poder assumi-la (e não de a ela apenas se submeter), e de se confrontar com o desafio de tornar-se mulher.

15. "Die erste führt zur allgemeinen Abwendung von der Sexualität (A primeira conduz a um afastamento geral da sexualidade.) Die zweite Richtung hält in trotziger Selbstbehauptung an der bedrohten Männlichkeit. (Na segunda direção, a mulher agarra-se com obstinada auto-afirmação à sua masculinidade ameaçada). Die Hoffnung, noch einmal, einen Penis zu bekommen, bleibt bis in unglaublich späte Zeiten aufrecht (A esperança de ainda conseguir um pênis permanece firme por tempos incrivelmente prolongados); wird zum Lebenszweck erhoben (ela é alçada a um objetivo de vida) und die Phantasie, trotz alledem ein Mann zu sein, bleibt oft gestaltend für lange Lebensperioden (e, apesar de tudo, a fantasia de ser um homem permanece freqüentemente configuradora por longos períodos de sua vida). Auch dieser 'Männlichkeitskomplex' des Weibes kann in manifest homosexuelle Objektwahl ausgehen (Este 'complexo de masculinidade' da mulher pode também resultar em uma manifesta escolha de objeto homossexual). Erste eine dritte, recht umwegige Entwicklung, mündet in die normal weibliche Endgestaltung aus (Somente uma terceira direção de desenvolvimento muito indireta termina na configuração final normal da mulher) die den Vater als Objekt nimmt (a qual toma o pai como objeto) und so die weibliche Form des Ödipuskomplexes findet, (e, assim, encontra a forma feminina do complexo de Édipo.). 


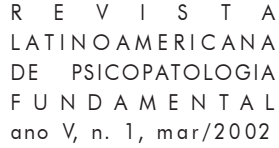

A castração, para ela, não é só castigo, é, sobretudo, promessa. Isso, porém, ela só consegue quando descobre, numa figura feminina, seja da mãe, seja de alguém que a represente, um ideal de ego, com o qual lhe seja possível identificar-se.

O desafio de se tornar um sujeito e, da posição de sujeito, assumir seus desejos, dizer sim à vida e construir o futuro, não é só do homem, ele é também da mulher. O ser humano (homem ou mulher) não nasce feito. A vida não lhe é dada feita, mas é dada como uma tarefa a ser feita, tarefa esta que nunca termina de ser realizada. É o que nos quer dizer Nietzsche, quando sentencia: "Torna-te o que tu és". ${ }^{16}$

Freud (1933, p. 345-48), no entanto, acredita que o desafio de tornar-se mulher é uma tarefa muito difícil, pois nem a fisiologia, nem a psicologia, nem mesmo a psicanálise pode dizer o que é e o que quer uma mulher. A psicanálise contenta-se com a tarefa de ajudar a menina a vir a ser uma mulher, partindo da criança que ela é com suas disposições bissexuais. ${ }^{17}$

É preciso, no entanto, reconhecer que Freud pouco se empenha em desvendar esta tarefa do tornar-se mulher, e pouco sucesso tem na tarefa de trabalhar o enigma que especifica a feminilidade. Por isso, particularmente nos dois últimos textos (o de 1933 sobre a feminilidade e o de 1937 sobre a análise terminável e interminável), seu discurso reveste a tonalidade de um discurso pessimista. Vamos acompanhá-lo neste terceiro e último passo da construção teórica de sua teoria sexual sobre a feminilidade.

\section{Terceira PARTE}

\section{Feminilidade e desamparo.}

O "rochedo de base" da castração e seu impacto sobre a feminilidade

Nesta terceira parte, vou confrontar Feminilidade e Castração num registro especial que, por minha conta e risco, chamarei de existencial ou ontológico. E a razão disso é porque, nele, a feminilidade articula-se com a noção fundamental do

16. Esta máxima do poeta lírico Píndaro foi assumida por Nietzsche, aparece no Ecce Homo e inspira o discurso de Zaratustra sobre o segredo da vida em Assim falou Zaratustra. Veja-se o que sobre isso escreve Roberto Machado, com a maestria que lhe é peculiar, no seu Zaratustra. Tragédia Nietzschiana, p. 140-2.

17. Veja-se sobre a tarefa de tornar-se mulher o que escreve Serge André no seu belo livro $O$ que quer uma mulher?, p. 189-207. 


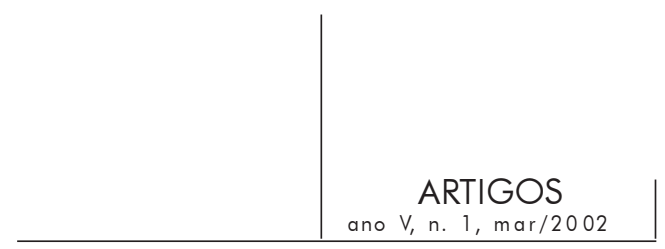

desamparo e com o conceito também fundamental de angústia do Real (Realangst), tal como foi reformulado na segunda teoria freudiana da angústia. ${ }^{18}$

A ligação da feminilidade com o "rochedo de base" da castração e, conseqüentemente, com o desamparo, é sugerida por Freud (1937, p. 357-92) na célebre passagem do artigo de 1937 sobre o fim da análise. Vejamos, rapidamente, o que nos diz esse texto.

\section{$O$ rochedo de base da castração}

Freud acabara de considerar os impasses a que está sujeito o analista, quando, por causa de seus "pontos cegos", ou seja, por causa de seus conflitos insuficientemente analisados, corre o risco de comprometer o bom andamento da experiência da análise. No capítulo oitavo, ele passa a considerar dois obstáculos insuperáveis para os objetivos e fins do trabalho analítico.

Os dois obstáculos estão ligados à distinção dos sexos e, apesar de diferentes, têm algo em comum. São eles: o Penisneid da mulher, e a resistência (das Sträuben) que o homem experimenta "contra sua posição passiva ou feminina face a outro homem" (gegen seine passive oder feminine Einstellung zum anderen Mann).

Freud (Ibid., p. 390) relaciona imediatamente esta resistência ao complexo de castração, rejeita a proposta que fizera Adler de chamá-lo de "protesto masculino" (männlicher Protest) e acredita que a expressão "repulsa da feminilidade" (Ablehnung der Weiblichkeit) é a "descrição correta desta tão estranha parte da vida psíquica dos seres humanos" (dieses so merkwürdigen Stückes des menschlichen Seelenlebens).

É assim que o termo de feminilidade entra em cena, neste momento da teoria sexual de Freud, intimamente correlacionado com o problema da castração.

Ferenczi supõe, como requisito, para o sucesso da análise, a superação desses dois obstáculos. Freud, porém, é de opinião que, neste ponto, Ferenczi foi muito exigente (anspruchvoll). De sua parte, ele acredita que é inteiramente sem sucesso (erfolglos) querer convencer a mulher "a abandonar, como irrealizável, o seu desejo de um pênis" (ihren Peniswunsch als undurchsetzbar anzugeben), bem como persuadir os homens de que "uma posição passiva diante de outro homem nem sempre tem o significado de uma castração" (eine passive Einstellung zum Mann nicht immer die Bedeutung einer Kastration hat). Portanto, aos olhos de Freud, o "rochedo de base" da castração é um obstáculo intransponível para o êxito da análise. É a grande pedra que está no fundo, além da qual não se pode ir.

18. Sobre a reformulação do conceito de Realangst no contexto da teoria freudiana da angústia. Cf. Zeferino Rocha. Os destinos da angústia na psicanálise freudiana, p. 133 e segs. 


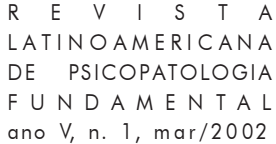

Assim sendo, ele conclui, de modo pessimista, que "a resistência impede qualquer mudança e tudo permanece como está" (alles bleibt, wie es ist). Dito isto, ele escreve a célebre frase:

Tem-se, freqüentemente, a impressão de se ter penetrado, com o desejo do pênis e o protesto viril, através de toda estratificação psicológica [durch alle psychologische Schichtung], até ao "rochedo de base" ["gewachsenen Fels"] e, desse modo, até onde se podia ir. (Ibid., p. 392)

E, pagando tributo ao seu mito biológico, conclui: Isso provavelmente tem que ser assim, pois, para o psíquico, o biológico representa realmente o papel do rochedo de base subjacente. A repulsa da feminilidade, de fato, nada pode ser senão um fato biológico, uma parte daquele grande enigma da sexualidade (Ibid., p. 391) ${ }^{19}$. Novamente, é no biológico em que se refugia Freud quando se confronta com o enigma da feminilidade.

\section{Feminilidade e feminino}

Para mim, a palavra "feminilidade" parece ambígua e inadequada para designar o "rochedo de base" da castração, a que se refere Freud neste texto. Esse rochedo indiscutivelmente remete ao desamparo e à angústia do desamparo. Por que, então, designar com o termo de "feminilidade" uma atitude existencial que não é propriedade característica, muito menos exclusiva, do sexo feminino?

Joel Birman (1999) trabalhou esta noção de feminilidade no contexto da teoria sexual freudiana. O livro Cartografias do feminino - brilhante e instigante como os demais livros deste autor que considero um dos mais atuantes no cenário da psicanálise brasileira contemporânea - confirma a ambigüidade com que a noção de feminilidade se reveste, quando é empregada para designar a finitude e o desamparo da condição existencial do ser humano.

Uma das expressões da ambigüidade do termo "feminilidade", quando relacionado com o desamparo, é a facilidade com que dele se passa para a noção de "feminino". Ora, se isto é correto do ponto de vista semântico (pois feminilidade e feminino são termos que indicam o modo de ser, de pensar e de se comportar próprios da mulher), o mesmo, no entanto, não acontece quando, ao termo feminilidade, é dada a conotação de desamparo.

$\mathrm{Na}$ feminilidade, Joel Birman ressalta o contraponto do referencial fálico e de suas ambições de auto-suficiência, onipotência e completude. Em oposição à totalidade

19. "Das muss wohl so sein, denn für das Psychische, spielt das Biologische wirklich die Rolle des unterliegenden gewachsenen Felsens. Die Ablehnung der Weiblichkeit kann ja nichts anderes sein als eine biologische Tatsache, ein Stück jenes grossen Rätsels der Geschlechtlichkeit”. 


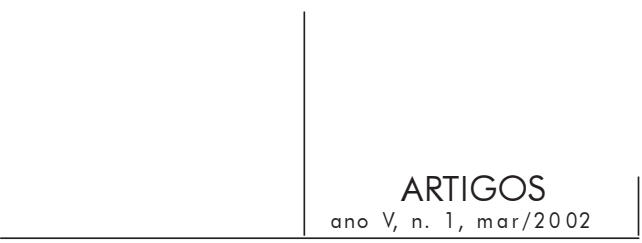

e dominação fálicas, a feminilidade destaca a concretude, a singularidade e a diferença e, ao centramento fálico, ela contrapõe o descentramento do sujeito e sua abertura para a alteridade, onde se dá o reconhecimento da diferença do outro. Articulada ao desamparo, a feminilidade põe em evidência a inexistência do falo como eixo de constituição da subjetividade (Ibid., p. 17-58).

Esta a razão por que a feminilidade, na perspectiva freudiana, é intimamente relacionada com o desamparo. Feminilidade e desamparo, escreve Birman, são as duas faces de uma mesma moeda. A feminilidade, porém, por causa de seu erotismo, é a face positiva e criativa do desamparo, em contraposição à face negativa que se manifesta na dor mortífera do masoquismo (Ibid., p. 201-17). Joel Birman acredita que, com o conceito de feminilidade, Freud (1937, p. 392) introduz um outro paradigma, que não o fálico, para discutir o problema da sexualidade feminina. ${ }^{20}$

Num trabalho anterior, tive oportunidade de abordar este tema da feminilidade quando me referi ao "rochedo de base" da castração no contexto da reformulação freudiana da teoria da angústia em geral, e do conceito de angústia do Real (Realangst) em particular. "A feminilidade", escrevia eu, "seria uma nova forma de ultrapassar a lógica fálica. Onde esta domina só existem duas categorias de seres: os fálicos e os castrados. Quem tem o phallus, ou o pênis como símbolo do phallus, teria, supostamente, uma superioridade ontológica sobre quem não o tem, pois não tê-lo é ser inferiorizado no próprio ser. Por isso quem o tem não quer perdê-lo e quem não o tem sente inveja de quem o possui. Pois bem, é precisamente a ausência desse phallus que Freud quer significar com o termo de feminilidade. (...) De maneira adequada ou não, a feminilidade é o lugar de confrontação do ser humano com sua finitude e incompletude" (RochA, 2000, p. 140).

Em "Inibição, sintoma e angústia", reformulando a teoria da angústia, Freud introduziu a angústia originária (Urangst) e fez dela a angústia arquetípica de todas as demais manifestações de angústia que aparecem no decorrer da existência humana. Ora, não é difícil mostrar que a angústia originária manifesta-se de modo especial na angústia do desamparo. Na metapsicologia freudiana, desamparo e castração estão intimamente relacionados, e a angústia de castração é que fundamenta o lugar de destaque e a nova dimensão que a angústia do real (Realangst) passa a ter na nova teoria da angústia, a ponto de Freud dizer que ela tem primazia sobre a angústia pulsional (Triebangst) (RocHA, 1999, p. 331-44).

20. Embora eu esteja de acordo com Birman, quanto a esta mudança de paradigma, pois na minha exposição chamei o registro da feminilidade de ontológico e existencial, eu, porém, não acredito que este modo de proceder tenha sido visto por Freud. Mesmo quando articulada com o "rochedo de base" da castração, a feminilidade, para ele, "não pode ser outra coisa senão uma realidade biológica" (kann ja nichts anderes sein als eine biologische Tatsache). 
Com a introdução da pulsão de morte não apenas um "além do princípio do prazer" foi introduzido na Metapsicologia, mas também um "além do princípio de realidade". O que vale dizer que também a realidade foi marcada com o signo da morte e do destino. E quando é assim considerada, a realidade reveste um aspecto inexorável que leva Freud a ver nela a figura mítica da deusa Ananke. A realidade inexorável aquela que aponta na direção do rochedo de base da castração - reveste então uma dimensão trágica e certamente não está muito longe do Amor Fati, de Nietzsche. Mas é hora de concluir.

\section{À guisa de uma conclusão}

A temática da feminilidade, quando se leva em consideração sua dimensão enigmática, sempre está aberta a novas e ulteriores reflexões.

\section{A lição do mito e da literatura}

Antes, porém, de terminar estas considerações, gostaria de mostrar brevemente como, diante da dimensão enigmática da feminilidade, e, em particular, na sua articulação com o desamparo, Freud encontra, no mito e na linguagem literária, um registro de reflexão cuja exploração é, inegavelmente, muito fecunda, não fosse por outra razão, ao menos pelo fato de que, como ensina Ricoeur, o "mito faz pensar".

No "Gradiva", Freud (1907, p. 14) lembra que, no campo da pesquisa psicanalítica,

... os poetas são aliados muito valiosos e o seu testemunho deve ser levado em alta conta, pois eles costumam cultivar uma quantidade de coisas entre o céu e a terra, com as quais a nossa sabedoria escolar ainda não nos deixou sonhar. No conhecimento das almas, eles estão bem adiante de nós, gente do dia a dia, porque eles haurem em fontes que ainda não exploramos para a ciência. ${ }^{21}$

Adélia Bezerra de Menezes (1995, p. 14-5), no seu belo livro Do poder da palavra, escreve: "A sensação obscura de que, na poesia, há algo que escapa ao racional, há um 'mistério' não desvendado, sempre intrigou os humanos”. E comentando, com muita beleza, as palavras supracitadas de Freud, ela acrescenta:

21. "Wertvolle Bundesgenossen sind aber die Dichter, und ihr Zeugnis ist hoch anzuschlagen, denn sie pflegen eine Menge von Dingen zwischen Himmel und Erde zu wissen, von denen sich unsere Schulweisheit noch nicht träumen lasst. In der Seelenkunde gar sind sie uns Alltagsmenschen weit voraus, weil sie da aus Quellen schöpfen, welche wir noch nicht für die Wissenschaft erschlossen haben." 


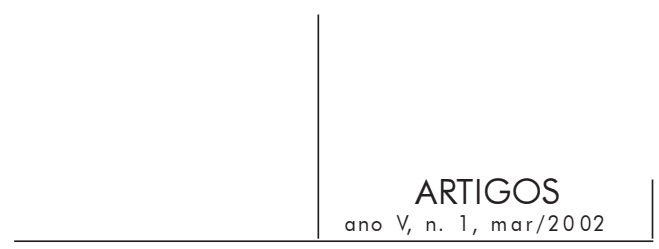

O Poeta ... apresenta-se como o ser a quem é dado, mais do que aos outros ("gente comum"), entrar em contato com a vida dos afetos, com o mundo do Id, que é o mundo da fantasia e do Desejo. Ele está como que mais perto das "fontes inconscientes" e seu conhecimento se faz via intuição (...) O Poeta é Orfeu, que desce à noite aos infernos para recuperar Eurídice, o fantasma do Desejo. Embora a regra do Hades lhe dite que não deverá olhá-la, se quiser trazê-la à superfície, Orfeu, no entanto, já às portas do Inferno, volta-se para vê-la e assim a perde para sempre.

Vejamos o que, nessa nova perspectiva mítico-literária, Freud (1913, p. 183-8) diz sobre o enigma da feminilidade, ao comentar brevemente duas passagens das peças de Shakespeare: o Mercador de Veneza e Rei Lear. O que está em jogo, nessas passagens, é o problema da escolha e do motivo da escolha que tem como objeto três figuras de mulher.

No Mercador de Veneza, aos três senhores que pretendiam a mão da sua filha, o rei prometeu que ela seria dada a quem fizesse a escolha acertada do cofre dentro do qual se encontrava o nome da desejada, e explicasse o motivo da escolha com palavras de louvor ao metal do cofre escolhido. Os cofrinhos eram três: um de ouro, outro de prata e o terceiro de chumbo. O vencedor foi quem escolheu o cofre de chumbo, cuja "simplicidade" lhe pareceu mais eloqüente do que as cobiçadas cores dos outros dois.

Na tragédia do Rei Lear, temos novamente em cena três figuras de mulher, desta feita, as três filhas do rei, pois era sua vontade repartir, ainda em vida, o reino entre aquelas de suas filhas que the demonstrassem, mediante um caloroso e entusiasmado discurso, seu grande amor e devoção filial. Para seu desapontamento, Cordélia, a filha mais jovem, que era a preferida, recusou-se a fazer o que lhe foi pedido, não porque não amasse seu velho pai, mas porque preferia calar-se e demonstrar seu amor em silêncio e de forma despretensiosa. Decepcionado, o rei a deserdou, e somente no fim da tragédia constatou seu grande erro, pois Cordélia era a única das filhas que verdadeiramente o amava e que lhe permaneceu fiel até o fim.

Na interpretação de Freud, a mudez, o silêncio de Cordélia e a "placidez" da cor do chumbo são inegavelmente símbolos da morte. De fato, na literatura de todos os tempos, nada parece simbolizar melhor a morte do que a mudez e o silêncio. Talvez por causa disso sintamos, diante da morte, uma imperiosa necessidade de silêncio. O morto mergulha em um silêncio inexorável. Ele se cala para sempre. Por mais que o chamemos pelo nome, ele não responde aos nossos apelos e se perde para sempre no silêncio de uma noite sem fim. Foi seguramente pela mediação deste símbolo da morte que as três figuras shakespearianas lembraram a Freud as três figuras míticas que os gregos chamaram de Moiras e os romanos de Parcas.

$\mathrm{Na}$ Grécia arcaica, a Moira, de forma impessoal, representava a força inexorável do Destino, ao qual estavam sujeitos os homens e os deuses, os mortais e os imor- 


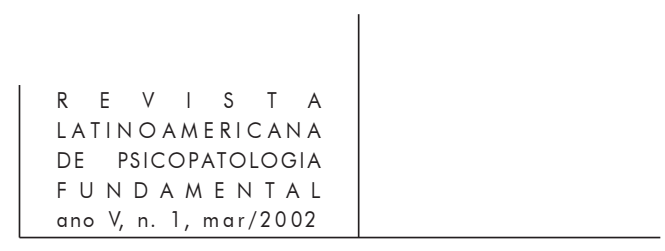

tais. Depois da epopéia homérica, ela passou a ser representada sob a forma de três figuras femininas denominadas: $\mathrm{K} \lambda \omega \theta \omega$ (a fiandeira), $\Lambda \alpha \chi \varepsilon \sigma ı \varsigma$ (aquela cuja função

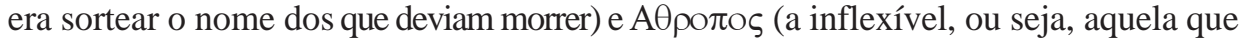
não volta atrás e cuja função era cortar o fio da vida). Breve, as Moiras eram divindades, cuja missão era fiar, sortear e cortar o fio da vida e executar o destino dos mortais.

$\mathrm{Na}$ Mitologia romana, as Moiras encontraram suas correspondentes nas figuras femininas das Parcas. Estas foram representadas, na maioria das vezes, como três velhas, cuja função era também tecer o fio da vida humana. Alguns artistas - como, por exemplo, Rubens, num célebre quadro que se encontra no Museu do Louvre figuraram-nas também sob a forma de três jovens, sentadas nas nuvens, mas sempre com a mesma função, ou seja, tecer o destino dos homens. Tanto as Parcas quanto as Moiras são, portanto, criações míticas, cuja finalidade é lembrar aos homens que, como parte da Natureza, eles também estão sujeitos à inelutável lei da morte e a inexorável realidade do Destino.

Freud evidentemente não se detém apenas nesta figura da Deusa da Morte para simbolizar o enigma da feminilidade. Ele lembra também o mito de Páris, no qual o célebre pastor é designado por Zeus para decidir qual das três imortais, Hera, Atená, ou Afrodite, deve ganhar a maçã de ouro que Eris - a Discórdia - deixou cair entre os deuses, por ocasião do banquete de núpcias de Tétis e Peleu.

A deusa Hera, para subornar o árbitro, ofereceu-lhe o Poder, e a deusa Atená, a Sabedoria. Mas o pastor finalmente escolheu a deusa Afrodite, pois esta, caso fosse a escolhida, lhe prometeu o amor de Helena, rainha de Esparta e a mulher mais bela do mundo (BRANDÃo, 1992, p. 238-41). Na linguagem do mito fica assim revelada, e ao mesmo tempo escondida, a força do Amor. O enigma da feminilidade não é só simbolizado pela deusa da Morte, ele o é, também, pela deusa do Amor.

Freud certamente não desconhecia as literaturas mais antigas, particularmente do Oriente, nas quais um culto especial era consagrado à Grande Deusa-Mãe. O mistério do nascimento nas culturas pré-históricas e a ignorância completa do papel que tinha o homem na reprodução contribuíram para aumentar o poder da Grande Deusa-Mãe. ${ }^{22}$

Nascimento, amor e morte. Nada mais sugestivo para simbolizar o enigma da feminilidade, se não nos esquecermos de que, segundo Freud, esta tríade marca o curso da vida do homem do começo ao fim. Primeiramente, a figura da Mãe que dá a vida (die Mutter selbst); depois, a figura da mulher amada (die Geliebte), escolhida

22. Essas e muitas outras informações sobre o poder da Grande Deusa-Mãe são documentadas por Sir James Frazer, The Golden Bough (1922), Margaret Mead, Male and female: a study of the sexes in a changing world (1949), Jacquetta Hawkes, Dawn of the gods (1958). Esses autores são citados por Rosalind Miles quando escreve sobre "A Grande Deusa". In: Rosalind Miles, A história do mundo pela mulher, p. 61, n. 8. 


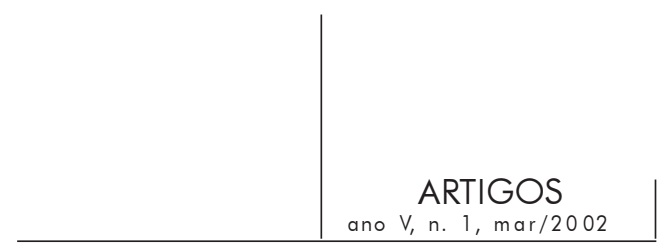

segundo o modelo daquela que foi nosso primeiro objeto de amor, e, finalmente, a Mãe-Terra (die Mutter Erde), que nos recebe, em seus braços, depois da morte. Cada uma dessas figuras de mulher revela um aspecto do enigma e do mistério da feminilidade.

Mas se Freud mandou que consultássemos os poetas para conhecer um pouco mais o sentido desse mistério, creio que o melhor que eu poderia fazer para encerrar esta conferência, seria dar a palavra a um verdadeiro poeta, precisamente àquele que, sem a menor sombra de dúvida, foi o poeta preferido de Freud. Estou me referindo a Goethe e a tudo o que de sublime ele escreveu sobre o "Eterno Feminino" (Das ewige Weibliche). Lembro, apenas, as maravilhosas palavras com as quais ele encerra o Fausto. Elas são majestosas na sua simplicidade:

$\begin{array}{ll}\text { Todo o efêmero } & \text { Alles Vergängliche } \\ \text { é apenas uma aparência. } & \text { ist nur ein Gleichnis. } \\ \text { O inacessível } & \text { Das Unzulängliche } \\ \text { aqui se torna acontecimento. } & \text { hier wird's Ereignis. } \\ \text { O indescritível } & \text { Das Unbeschreibliche } \\ \text { aqui é feito. } & \text { hier ist's getan. } \\ \text { O Eterno-Feminino } & \text { Das Ewig-Weibliche } \\ \text { para o alto nos arrasta. } & \text { zieht uns hinan. }{ }^{23}\end{array}$

\section{Referências}

AnDRÉ, Serge. O que quer uma mulher? Trad. Dulce Duque Estrada. Rio de Janeiro: Jorge Zahar, 1987.

Birman, Joel. Cartografias do feminino. São Paulo: Editora 34, 1999. e NicÉAs, Carlos Augusto (orgs). O feminino: aproximações. Rio de Janeiro: Campus, 1986.

Brandão, Junito. Dicionário mítico-etimológico. Petrópolis: Vozes, 1992. v. II.

Citati, Pietro. Goethe. Trad. Rosa Pereira d'Aguiar. São Paulo: Companhia das Letras, 1990.

De Rougemont, Dénis. O amor e o ocidente. Trad. Anna Hatherly. Lisboa: Veja, s/d.

Freud, Sigmund (1905). Drei Abhandlungen zur Sexualtheorie. Studiensausgabe (SA.) Band V. Fischer Taschenbuch Verlag, 1982. (1907). Der Wahn und die Träume in W. Jensens “Gradiva”. SA. Band X. Fischer Taschenbuch Verlag, 1982.

(1910). Eine Kinderheitserinnerung des Leonardo da Vinci. SA., Band X. Fischer

Taschenbuch Verlag, 1982.

23. Cf. J.W. von Goethe. Faust 12 104-11. Veja-se o belo comentário de Pietro Citati no seu livro Goethe, p. 454-5. 
(1912). Beiträge zur Psychologie des Liebeslebens - II Über die allgemeinste Erniedrigung des Liebeslebens. SA. Band V. Fischer Taschenbuch Verlag, 1982. (1913). Das Motiv der Kästchenwahl. SA. Band X. Fischer Taschenbuch Verlag, 1982.

(1914). Zur Einführung des Narzissmus. SA. Band III. Fischer Taschenbuch Verlag, 1982.

(1923). Die infantile Genitalorganisation. SA. Band V. Fischer Taschenbuch Verlag, 1982.

(1924). Der Untergang des Ödipuskomplexes. SA. Band V. Fischer Taschenbuch Verlag, 1982.

(1925). Einige psychische Folgen des anatomischen Geschlechtsunterschieds. SA.

Band V. Fischer Taschenbuch Verlag, 1982.

(1925a). Um estudo autobiográfico. ESB. Rio de Janeiro: Imago, 1972. v. XX.

(1931). Über die weibliche Sexualität. SA. Band V. Fischer Taschenbuch Verlag, 1982.

(1933). Die Weiblichkeit. In Neue Folge der Vorlesungen für Einführung in die Psychoanalyse. SA. Band I. Fischer Taschenbuch Verlag, 1982.

(1937). Die endliche und unendliche Analyse. SA. Ergänzungsband.

Jones, Ernest. Théorie et pratique de la psychanalyse. Paris: Payot, 1969.

Lacan, Jacques. Escritos. Trad. Vera Ribeiro. Rio de Janeiro: Jorge Zahar, 1998.

Laplanche, Jean. Problemáticas II. Castração. Simbolizações. Trad. Álvaro Cabral. São Paulo: Martins Fontes, 1988.

Freud e a sexualidade. O desvio biologizante. Trad. Lucy Magalhães. Rio de Janeiro: Jorge Zahar, 1997.

Machado, Roberto. Zaratustra. Tragédia nietzschiana. Rio de Janeiro: Jorge Zahar, 1997. Menezes, Adélia Bezerra. Do poder da palavra. Ensaios de literatura e psicanálise. São Paulo: Livraria Duas Cidades, 1995.

MiLes, Rosalind. A história do mundo pela mulher. Trad. Bárbara Heliodora. Rio de Janeiro: LTC-Livros Técnicos e Científicos/Casa-Maria Editorial, 1989.

NicÉAs, Carlos Augusto. Primado do falo e castração feminina. In: BiRman, Joel e NicÉAs,

Carlos Augusto. O feminino: aproximações. Rio de Janeiro: Campus, 1986.

Ricoeur, Paul. De l'interprétation. Essai sur Freud. Paris: Seuil, 1965.

Rосна, Zeferino. Desamparo e Metapsicologia - para situar o conceito de desamparo no contexto da metapsicologia freudiana. Síntese. Revista de Filosofia. Belo Horizonte, v. 26, n. 86 , p. 331-44, 1999.

Os destinos da angústia na psicanálise freudiana. São Paulo: Escuta, 2000.

\section{Resumos}

En el presente trabajo deseo someter a la discusión de los lectores, el modo en que Freud se confronta con el problema de la castración en tres momentos decisivos de la 


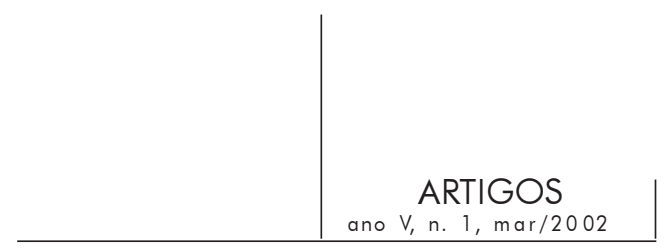

trayectoria de su teoría sobre la sexualidad femenina. La primera discute el problema de la castración biológica de la mujer y de su consecuente sexualidad que Freud considera inferior si comparada con la sexualidad masculina. La segunda muestra la importancia y el destino de la castración simbólica en la estructuración del psiquismo y en la tarea de tornarse mujer, a pesar de que esto no aparezca manifiestamente en el texto freudiano. Finalmente, la tercera parte relaciona femineidad y desamparo, en un registro que podría llamarse ontológico, teniendo como referencia el artículo del 1937 sobre el análisis terminable e interminable, en el cual Freud resalta la "roca de base" de la castración a pesar de no darle la interpretación que nos parece mas adecuada.

Palabras clave: Sexualidad femenina, castración, femineidad, desamparo

Dans le présent travail, je souhaite offrir à la discussion des lecteurs le mode comme Freud se confronte au le problème de la castration à trois moments décisifs de sa trajectoire de sa théorie de la sexualité féminine. Les trois parties du travail prétendent reprendre cette trajectoire. La première discute le problème de la castration biologique de la femme et de sa sexualité conséquente que Freud considère inférieure comparée à la sexualité masculine. La deuxième montre l'importance et le destin de la castration symbolique dans la structuration du psychisme et dans l'opération du devenir femme, bien que cela n' apparaîsse pas dans dans le texte manifeste du discours freudien. Enfin, la troisième partie met en relation la féminité et l'abandon dans un registre qui peut être dit ontologique, à partir d'une référence à l'article de 1937 sur "l' Ánalyse teminable et interminable" dans lequel Freud considère la castration comme "roc d'origine”, sans toutefois lui donner l'interprétation qui nous semble la plus adéquate.

Mots clés: Sexualité féminine, castration, féminité, abandon

The intention in this article is to describe how Freud faces the problem of castration in three decisive stages of the course of his theory on female sexuality. The three parts of the article seek to describe this course. The first discusses the problem of biological castration of women and their consequent sexuality, which Freud considers inferior to male sexuality. The second shows the importance and consequences of symbolic castration in the structuring of the psychism and in the task of becoming a woman, although this does not clearly appear in Freud's text. Finally, the third part relates femininity to helplessness in a register that could be called ontological, based on Freud's article of 1937 on "Analysis Terminable and Interminable", where Freud stresses the "solid rock" of castration, without, however, giving it what we would consider the most adequate interpretation.

Key words: Female sexuality, castration, femininity, helplessness

Versão inicial recebida em novembro de 2001

Aprovado para publicação em janeiro de 2002 